\title{
The Euphausiidæ in the Neighbourhood of Plymouth and their Importance as Herring Food.
}

\author{
By \\ Marie V. Lebour, D.Sc., \\ Naturalist at the Plymouth Laboratory.
}

With Plates I-VI at the end.

AN investigation into the euphausiids in the Plymouth waters was undertaken on account of the fact that on examining adult Herring for food it was found that Nyctiphanes Couchii (Bell) was of great importance, and occurred in enormous numbers in a large proportion of the Herring caught in the earlier half of the period of the Herring fishery.

Very little is known of the life-history of Nyctiphanes Couchii, and a detailed knowledge of its habits is wanting. In trying to elucidate the facts it was found that not only is this euphausiid extremely common, both as young and adult, but that three others new to the Plymouth waters occur abundantly at times and breed therein. These are Meganyctiphanes norvegica (M. Sars), Thysanoessa neglecta (Kroyer) and Thysanoessa inermis (Kroyer), the last being recorded by Norman (1906) as Rhoda inermis, from material received from Gough, taken once south of the Scillies, and once from Station 4, farther south. The other records are apparently new. It was thus found that the investigation involved four life-histories in order to clear up one, and it is probable that all four species are important as fish food, and therefore any new information as to their biology is of value.

In the autumn of 1923 it was decided to try to find out the food of the Herring from the beginning of its advent into the regions of the Channel near Plymoutb until its disappearance after spawning. It is well known that about November these Herring enter the Channel and occur in such abundance that there is an annual fishery during the months of November, December and January. It is certain that the fish approach the coast to spawn, shedding ova from December to the end of January or into the beginning of February and then disappear. No records could be found 
of the food of the Herring in this locality during these months. It is a general view among the fishermen and those interested in the fishery that the Herring after spawning does not eat, or even that at this season, whether about to spawn, or during and after spawning, it does not eat. Workers in other localities, however, especially in Scotland, have shown that they may eat at all times, although usually not so much when spawning. Our own records, although based on only a few specimens on each date, show that the stomach may be full of food before, during and after spawning; but that many more empty fish occur during and after spawning, which agrees with records of other observers from different localities. The Herring were not examined from the first date they appeared (ca Nov. 1st), but examination only began on November 21st, when at first a dozen at a time, afterwards four every other day, with now and then a double supply were undertaken. The fish were procured from the local or East Country boats as they came in, and the general locality from whence they were fished was ascertained. The detailed records of the food are kept for reference.

The food was always plankton, and nearly always consisted of small crustacea. Sometimes the stomach was largely inflated by food, which generally in these cases proved to be Nyctiphanes Couchii. This euphausiid has lately been found in great abundance outside the Sound, one night haul taken in December during the Herring season bringing up many thousands from the surface. Meganyctiphanes norvegica is known to be an important food for Herrings and other plankton-eating fishes in the Irish Sea (Holt and Tattersall, 1905) and in other localities, and this and other euphausiids in the Scottish seas and lochs serve largely as Herring food. Nyctiphanes Couchii is found also to be of great importance as food for Mackerel and Pilchard caught with the Herring at Plymouth, all these fishes eating it in large quantities and having enormously distended stomachs full of this crustacean. Certain Mackerel had eaten young Pilchards (ca $2 \frac{1}{2}-3$ inches long), which themselves had eaten Nyctiphanes in numbers, so that both directly and indirectly Nyctiphanes serves as Mackerel food. So far, however, no other euphausiid has been identified inside any of these fishes from Plymouth.

Copepods come next in importance, or perhaps are equally important, or more so, although the Herring stomach is never so distended as it is with Nyctiphanes. In our samples Candacia armata stands out as the most frequently eaten species, and at this time of year it is the copepod most commonly taken in the Young Fish Trawl or townets in the regions of the Herring fishery, usually from the lower layers. Other copepods eaten by the Herring at Plymouth are: Temora longicornis, Calanus finmarchicus, Pseudocalanus elongatus, Corycous anglicus, Metridia lucens, Centropages typicus and Acartia 
Clausi. Very little food other than copepods and Nyctiphanes was seen. During spawning time a few Herring had eaten Herring ova or newly hatched Herring.

On the whole, at this season, the examination points to the two crustaceans, Nyctiphanes Couchii and Candacia armata, as the most important food of the Herring in the region of Plymouth.

It was found that out of 132 Herring examined from November to January, of which 78 were empty, out of the first 65 , from November to December, about one-third were empty, whilst out of the last 67 , from December to January, about two-thirds were empty. Of the 43 which contained food in the first half, half had eaten Candacia armata (22 out of 43) and nearly half had eaten Nyctiphanes Couchii (19 out of 43). Of the 19 which contained food in the second half, 8 had eaten Candacia and only 4 had eaten Nyctiphanes. It thus seems that Candacia is eaten by the greater number, but Nyctiphanes is present in enormous quantities, far greater than Candacia, when eaten.

Running females sometimes were full of food, one with newly hatched Herring, Herring eggs and Sagitta, two full of Nyctiphanes Couchii, two containing many Temora lonigicornis.

One spent female was full of Herring eggs, one full of Nyctiphanes Couchii.

One mature male contained Herring eggs.

The importance of Nyctiphanes Couchii as food in the early Herring season seems to be obvious, although only a few specimens were examined. It is hoped to investigate the matter further this year as soon as the Herring appear in the autumn.

An account of the detailed distribution of the euphausiids is reserved for a future occasion. In this I am having much help from Mr. O. D. Hunt, who took special night hauls. I also have to thank Mr. F. S. Russell for material sorted out from Young Fish Trawl and Metre tow-net collections. It is enough to state here that the adults and older larvæ all appear to live very near the bottom in the daytime and come up to the surface at night, although the young larvæ seem to keep near the surface, and it seems that the adult Nyctiphanes Couchii occurs at all the seasons in the district from beyond the Sound outwards, its young being found all the year round with a probable maximum breeding time in the spring. On the other hand, the records of Meganyctiphanes norvegica and Thysanoessa neglecta and $T$. inermis point to a habitat farther out, with a spring breeding time and a probable nearer approach to the coast during the breeding season, as larvæ are found usually much closer in than the adults.

The value of the present observations lies largely in the fact that so much has been done on the living organisms, the larvæ of Nyctiphanes 
Couchii being reared from the parent egg-sac up to the last Calyptopis stage, and later stages being kept alive from the plankton and reared through various moults. Eggs have been obtained from Thysanoessa neglecta and $T$. inermis, although unfortunately the rearing of these failed, and live eggs attributable to Meganyctiphanes norvegica, although not obtained from the parent, were kept until nauplii emerged from them, second nauplii from these and metanauplii following. Various later stages of all these three species were kept alive and reared through several moults and series of plankton specimens were kept and preserved, so that the species could be identified. The present paper only carries these in detail, as far as the last Calyptopis stages, the two species of Thysanoessa in the three Calyptopis stages not being separated. The later stages are reserved for a future paper.

The fact that the Nyctiphanes from the surface contained more food than those from near the bottom points to their coming to the surface to feed, and as the Herrings also come to the surface at night, it is probable that they feed on the euphausiids at that time. The Nyctiphanes examined nearly always contained some dark substance in their stomachs, but in those from the bottom there was much more debris than fresh organisms, which occurred in numbers in those from the surface. The food is brought to the thoracic limbs by a current from behind, set up by the movement of the abdominal limbs, the thoracic limbs forming a sort of basket-like receptacle for the accumulated food. Although the food organisms found inside them were usually unicellular, they sometimes feed on Sagitta and crustacea. If one of their number died when in the aquarium it would very likely be eaten by the others. The commonest food organisms seen inside were the diatoms Paralia sulcata and Hyalodiscus stelliger, Paralia being the most abundant; Coscinodiscus excentricus and $C$.radiatus were also commonly taken and the peridinians Prorocentrum micans and Exuviella perforata. The Nyctiphanes examined for food were all from winter hauls, and these food organisms were all common in the plankton at that time.

In a sample of 50 examined from a surface night haul-December 13th, 1923, 49 contained many Paralia, in most cases together with other diatoms and peridinians. On other occasions out of 25 examined from the surface, 10 contained diatoms, chiefly many Paralia, from 25 from midwater, 18 contained diatoms, chiefly Paralia, and in 25 from near the bottom, 8 only contained diatoms (Paralia) and these singly, whilst the remainder contained sand and debris alone. From another haul near the bottom in February, 6 out of 16 contained single diatoms, the rest debris. One examined after having been kept alive in a glass jar for ${ }^{\circ}$ 5 days and given fine plankton, contained 6 Hyalodiscus stelliger, 2 Grammatophora serpentina, much debris and sand. 


\section{The Life History of Nyctiphanes Couchii (Bell).}

It has been known ever since the species was first recognised that the female of Nyctiphanes Couchii carries her eggs in a pear-shaped sac, and it is figured by Bell (1853), who first described it as Thysanopoda Couchii. His specimens were procured from the stomach of a Mackerel caught on the Cornish coast. As Holt and Tattersall (1905) rightly observe, however, the egg-sacs are depicted in Bell's figure hanging from their narrow ends, whereas in reality they hang with their broad ends fixed as in the figure given by these authors who observed ovigerous females from 10 to $16 \mathrm{~mm}$. in length, and state that in one specimen the ovisac contained naupliid larvæ, the breeding season reaching its maximum some time in May. This appears to be all the information available up to the present time on the youngest larvæ of Nyctiphanes Couchii, although Sars (1885), in the Challenger reports, figures and describes the metanauplius, three Calyptopis stages and adults of $N$ yctiphanes australis, evidently a very closely related species, the larvæ of which bear a close resemblance to those of Nyctiphanes Couchii. His specimens, however, are apparently all described from preserved material.

The first ovigerous female noticed in the neighbourhood of Plymouth was a dead one with egg-sacs from a surface night haul, 13.12.23. The sacs, however, were injured, and this was the only specimen seen to be breeding until April, 1924, although calyptopis stages were taken in February and March. Again in a night haul, Station E1, 10 miles S.W. of the Eddystone, 9.4.24, several females with egg-sacs were taken, two of which were kept alive, measuring $14 \mathrm{~mm}$. and $15 \mathrm{~mm}$. in length. One had the eggs in an early stage of development in the sacs, and this was kept alive for several days in a glass bowl, the eggs unfortunately dying. The second, which was preserved after a day, had the egg-sacs broken and the larvæ contained therein were emerging. Other specimens, $14 \mathrm{~mm}$. to $15 \mathrm{~mm}$. long, preserved from the same hauls, contained larvæ. The eggs are spherical and transparent, measuring from $0 \cdot 36 \mathrm{~mm}$. to $0.40 \mathrm{~mm}$. across, the egg itself coming close up to the capsule (Plate I, Fig. 1). Unfortunately, the development of the early stages could not be studied further, owing to lack of material, but all the larvæ seen contained in the sacs of several different females were either a kind of nauplius (which, however, was unlike any known euphausiid nauplius in that its mandible consisted of a uniramous stump instead of the typical biramous swimming limb) or a stage between this and a typical metanauplius, for which I have proposed the term pseudo-metanauplius. The uniramous mandible in the nauplius is an exceedingly interesting adaptation to a long period of protection. The youngest and simplest nauplius (Plate I, Figs. 2 and 3) contained in the sac measured $0.40 \mathrm{~mm}$. 
to $0.44 \mathrm{~mm}$. long and ca $0.32 \mathrm{~mm}$. broad, of a simple oval shape, showing muscles inside the body, but no alimentary canal and having two small processes projecting behind. It has three pairs of limbs, antennules projecting forwards, simple, with three short setæ, antennæ usually projecting outwards laterally, biramous, the limbs with three and five setæ respectively, and the mandibles, which are uniramous, projecting forwards as elongated knobs. It was not possible to find an earlier stage than this, although one may be present. Apparently this simple nauplius changes inside the sac into a form like a metanauplius, but still having a thin skin over the limbs behind the mandible and covering the carapace. A later stage of the nauplius shows the abdomen formed and three limbs under the skin (Plate I, Fig. 4). It is this metanauplius-like form which I have termed the pseudo-metanauplius, and it is at this stage that the larva emerges from the sac (Plate I, Fig. 5).

On April 24th, 1924, another female, $16 \mathrm{~mm}$. long, with egg-sacs, occurred from Station L4, half-way between Rame Head and the Eddystone, and this was successfully kept alive until the larvæ left the sacs. When captured there were larvæ moving in the sacs apparently in the naupliar stage, but these were not examined for fear of injury, and it was not until April 30th that the larvæ emerged. The young of Nyctiphanes Couchii thus does not emerge as a typical nauplius, but as an early metanauplius, which almost immediately sheds an excessively thin skin, and appears as a true metanauplius. In the absence of a proper term for the first of these two stages I suggest the name pseudo-metanauplius. The pseudo-metanauplius (Plate I, Figs. 5 and 6) measures $0.56 \mathrm{~mm}$. long. It has a slightly projecting tail, which is held under the body and is armed with 4 to 8 spines, according to its age. The postnaupliar limbs, three behind the mandibles, are visible as simple rounded knobs, and in front of these are seen the rudiments of the under lip. These are all held down by a thin skin, which also encloses the true metanaupliar carapace and anterior lip. The eye is visible under the skin and also the rudiments of the ocular plates, from which the compound eyes are developed, and a striated portion each side shows the rudiments of the ocular luminous organs. The alimentary canal, liver and heart can also be seen. The antennules with three long setæ project in front, and the rami of the antennæ possess five and six setæ respectively. Almost immediately after emerging the pseudo-metanauplius sloughs a very thin skin and becomes a typical metanauplius (Plate I, Figs. 7, 8, 9). This measures $0.57 \mathrm{~mm}$. long, the tail bearing 6 to 8 spines, the two second from the outside being the longest. The carapace is now free and projects at the sides. It has no teeth round the margin, which is perfectly simple, and thus resembles the metanauplius stage of Nyctiphanes australis, described by Sars (1885), the limbs also resembling this 
species with the exception of a few details in the number of setæ. The fact now shown that the larva of Nyctiphanes Couchii emerges from the sac at so late a stage probably accounts for the non-appearance of any stages earlier than the metanauplius in Sars' material, for the species seem to be so closely related that they would almost certainly resemble one another in their early larval stages.

All these stages of Nyctiphanes Couchii are quite colourless and transparent.

The metanauplii were kept alive in glass finger bowls, into which were introduced a small quantity of a pure culture of the diatom, Nitzschia closterium, but in no case did any of them eat. The first Calyptopis emerged from these on April 2nd and 3rd. At first these did not eat and were quite colourless, but after three days they ate Nitzschia, and immediately after eating the typical pigment appeared, consisting of two conspicuous orange-red chromatophores on the tail. Some of the bowls were kept dark and others were placed on white grounds, but the coming up of the pigment was in all cases the same. The natural food of the Calyptopis stages seem to be diatoms and other unicellular organisms, as was shown from plankton specimens.

The first Calyptopis is easily recognisable in the plankton by its distinctive coloration, and is very commonly present, especially in the early spring, and this is the earliest stage of Nyctiphanes Couchii so far found in the plankton, which is probably to be accounted for by the fact that such a short time is spent in the metanauplius stage. From February through March and April it may be found in abundance, usually at, or near, the surface. The adult, although living in the daytime near or at the bottom, comes up to the surface at night, and there it apparently sheds its offispring, which only go down again at a much later stage. In five days the first Calyptopis changed into the second, and this in ten days into the third, after which unfortunately all the specimens died. The larvæ were thus reared in the free state from the pseudo-metanauplius to the third and last Calyptopis, and enough was learnt from this series to make all these stages easily recognisable in the plankton. In one case a first Calyptopis, April 17th, 1924, was kept alive and changed into the second on the 19th, this to the third on the 25th, and this to the first Furcilia on the 31st, when it was killed and preserved.

The first Calyptopis (Plate II, Fig. 1) typically measures ca one millimetre in length. It may, however, be slightly longer or shorter, and enlarges after emerging from its metanaupliar skin, the size given being for one full grown and coloured. Its carapace is an elongated oval covering the ocular plates and head region and measuring $0.64 \mathrm{~mm}$. in length. The abdomen is unsegmented, but in front merges into the thoracic region, the segments of which can be distinctly seen, although very 
narrow and without trace of limbs. The telson is square at the extremity with truncated corners, and bears twelve terminal spines besides an additional one each side below, or at the level of the chromatophores. Of the terminal spines two occupy the eorners each side, eight are in a straight line terminally, the outside spines of the eight being the longest. The single dark red eye is situated in the centre of the head with an ocular plate on each side, bearing the rudiments of the ocular luminous organs. The antennules consist each of two segments with five setæ, two of which are sensory, the inner ramus barely showing and having three small setæ. The antennæ forming powerful swimming organs, one ramus with four terminal and two lateral setæ, the other distinctly jointed with seven setæ. The mandibles (Plate II, Fig. 2) are strong biting jaws with a forwardly projecting process and strong muscles. Both upper and under lips are well developed. The first maxilla (Plate II, Fig. 3) has two masticatory lobes (the first with eight setæ, the second with two strongly spined teeth with a spine in between) and two joints, the inner with six setæ, the outer with four. The second maxilla (Plate II, Fig. 4) has five small lobes on the inner side of the base, well provided with setæ, and a terminal blade with a seta on its outer base and four terminal setæ. The first thoracic limb (Plate II, Fig. 5) consists of a two-jointed base (the proximal joint with three, the distal with six setæ and a thick horn-like spine) and two rami, the inner two-jointed (the proximal joint with a seta and a thorn-like spine, the distal with four setæ), the outer of one piece with a seta at its outer base and four terminal setæ. These all are directed forwards, as shown for the second Calyptopis (Plate II, Fig. 6), their long inner spines forming a basket for the food, but the limbs also helping by their movement to bring the food towards the mouth. The abdomen in all the Calyptopis stages is capable of much movement up and down, and is extremely flexible, being usually bent at an angle with the body. The structure of the limbs is essentially the same in all three Calyptopis stages, and strongly resembles those of Nyctiphanes australis described by Sars.

From the first Calyptopis comes the second (Plate II, Fig. 6), which has advanced greatly in size, in segmentation and in the development of another terminal spine on the telson. It measures $1.44 \mathrm{~mm}$. in length, and besides the pigment on the telson it has orange-red pigment in the mouth region and also usually near the ocular organs where the compound eyes will appear. The carapace measures $0.76 \mathrm{~mm}$. long, and at the side has a small but distinct tooth which is characteristic of the adult Meganyctiphanes norvegica, but not present in the adult Nyctiphanes Couchii. It, however, persists through many larval stages. Zimmer (1909) states that this tooth is present in many young forms where it is absent in the adults. The abdomen has five segments and the telson; 
the thorax with seven, the first having a knob representing the second thoracic limb. The telson has the usual pair of orange-red chromatophores, and is armed with thirteen terminal and two lateral spines. The antennules have a three-jointed base and a biramous termination, the outer with five, the inner with three setæ. There is also a small seta at the outer base of the outer ramus, which may be double and which apparently is absent in the corresponding stage of Nyctiphanes australis, although present in the following stage. The antennæ are essentially the same as in the first Calyptopis but longer, the setæ reaching to the end of the carapace. The mandibles are larger, but these and the other limbs present bear a very close resemblance to those of the first Calyptopis.

A rather longer interval (ten days) takes place between the change from second to third Calyptopis than in the preceding changes, but the third and last stage has increased largely in size. This (Plate III, Fig. 1.) measures $1.92 \mathrm{~mm}$. in length, the carapace being $0.96 \mathrm{~mm}$. The abdomen has six segments, and there are the beginnings of uropods on the telson, which still has thirteen terminal and two lateral spines, the pigmentation being much the same as in the second Calyptopis, the compound eyes beginning and being distinctly coloured. The thorax is much the same as in the preceding stage, as are also the first thoracic limbs and those in front of it, the antennule having developed a pointed projection coming from the outside of the proximal segment of the base.

This is at present as far as it was possible to go by rearing this year with the available material. It is, however, now these larval stages are accurately known, possible to pick them out from the plankton and rear them further. In this way the second Calyptopis has been obtained from the first, the third from the second and the next succeeding stage (first Furcilia) from the third and last Calyptopis. Various other stages have also been secured, all having the typical pigment on the telson. At a small size it is possible to recognise certain adult characters in the young, e.g. spine over telson together with processes on the antennule, so that now at any stage it can be distinguished from other species.

The Furcilia stages are characterised by having the eyes freely exposed and no longer covered by the carapace, but they still retain the biramous swimming antennæ. The first Furcilia of Nyctiphanes Couchii (Plate VI, Fig. 8) has the usual characteristic pigment with the addition of a chromatophore on each side of the thorax. It measures $2.8 \mathrm{~mm}$. in length, the carapace measuring $1.12 \mathrm{~mm}$., and leaving the eyes fully exposed at the sides, whilst dorsally it protects their bases by a squarish shield. The lateral spine on the carapace is still present. There is a simple projection hanging down from each side of the first abdominal segment, representing 
the first abdominal limb, and behind under the skin a second smaller pair is seen. The second thoracic limb is longer, although still only a simple process, and behind two smaller pairs of knobs are present representing the third and fourth pairs of thoracic limbs. The eyes are very conspicuous and well developed.

After this much fewer specimens were seen of later Furcilia stages, only one occurring here and there. It is hoped to fill in these gaps later. Next come the Cyrtopia stages, in which the antennæ no longer serve for swimming, and these almost insensibly merge into the post-larval forms which are like miniature adults. It has not yet been possible to follow up these later larval stages in detail, but enough has been seen to show that many of the adult characters are assumed at a very small size-much smaller than any of the other local species. At $6 \mathrm{~mm}$. the telson is almost like that of the adult, the antennules have fairly long filaments and the spine has appeared above the telson. The body up to this stage and longer is pellucid with the red luminous organs showing up very conspicuously in the later stages, red at the base of the telson and the proximal joints of the limbs and in the region of the mouth.

Females with egg-sacs were taken up to the middle of April, first Calyptopis stages from December to April, second Calyptopis from February to May. Later stages all through the summer and autumn. The younger larval stages, especially the Calyptopis, were nearly always at the surface or midwater, the post-larvæ near the bottom, rising to the surface at night, the usual habit of the adults.

It seems from these observations that although a few individuals may be breeding all the year round, the majority breed in the early spring, April perhaps being the maximum month, slightly earlier than in the Irish Sea. Nyctiphanes Couchii at some stage may be found all the year round, and apparently breeds and lives in a wide area in the neighbourhood of Plymouth, preferably in water of a depth of about 20 fathoms or more, although occasional examples may be met with close inshore, especially larval stages which have probably moved in with the tide.

It is hoped to deal with its detailed distribution in a future paper.

To sum up what we now know of the life-history of Nyctiphanes Couchii. This species breeds chiefly in the spring in the Plymouth waters, the female carrying her eggs in a thin-walled sac, the eggs hatching inside the sac and being retained therein for a considerablê time as nauplii, which, as an adaptation to this special method of protection and unlike any known euphausiid, have no biramous mandible, but only a uniramous stump. The young escape from the egg-sac as a kind of metanauplius which has the carapace and limbs behind the mandibles still covered by 
a thin skin, this stage being here termed the pseudo-metanauplius. Almost directly after hatching this changes to a true metanauplius. From the metanauplius comes very quickly the first Calyptopis, which only now begins to eat, and as soon as it eats begins to have pigmenttwo orange-red chromatophores on the telson. From the first comes the second, and from the second comes the third and last Calyptopis. Then follow several Furcilia stages, Cyrtopia and post-larval, the adult characters arising at a very small size.

Up to the present time Nyctiphanes Couchii is the only euphausiid recorded from the Plymouth neighbourhood, but whilst investigating its life-history the three others mentioned above were found to be abundant at certain times of year-Meganyctiphanes norvegica, Thysanoessa neglecta and Thysanoessa inermis. The last, formerly known as Rhoda inermis, is regarded by Hansen (1911) as synonymous with Thysanoessa neglecta, that worker regarding the long-legged form as only a variety of the same species. Although there has not yet been sufficient time nor opportunity to go minutely into this matter, certain considerations seem to show that they are at least distinct species, although the adults are so extraordinarily similar. It is hoped to investigate these species further, but the few notes so far put together are given here, as they are certainly of some interest

\section{The Life-History of Meganyctiphanes norvegica (M. Sars).}

Meganyctiphanes norvegica has hitherto apparently not been recorded from the Channel, although common in many parts of Britain, especially the Irish Sea and the Clyde area. Its life-history is one of the best known, as Sars (1897) has described its eggs and early larvæ from Norway, and Brook and Hoyle (1888) have taken them in the Clyde area, although not describing them in detail. Recently Elmhirst (1923) has taken them in Millport and presumably reared them, although very little detail is given. He states that "This species seems to pass through 2 Nauplius, 1 Metanauplias, 3 Calyptopis, 6 Furcilia and 5 Cyrtopia stages before the adult form is attained."

Only one adult has been found in the Plymouth area (a male), although larval forms which must be attributed to this species are found in great abundance in the same places as Nyctiphanes Couchii occurs and often taken with these. For the sake of comparison with Nyctiphanes the early stages found in the neighbourhood of Plymouth are here described, although one can only infer that the eggs and younger stages belong to this species as the eggs have not been obtained from the parent. There seems to be, however, abundant evidence that these belong to Meganyctiphanes, as they are exactly similar to those described by Sars, and 
the later larval stages can be traced up to post-larvæ having the adult characters.

In February, 1924, eggs occurred abundantly in the plankton. These contained developing nauplii, which emerged and changed into second nauplii, these into metanauplii and the metanauplius into the first Calyptopis. Afterwards second Calyptopis came from first, and third from the second, and many Furcilia, Cyrtopia and post-larval stages were found, and could be easily recognised in the fresh state. Although the Calyptopis stages and early Furcilia closely resembled Nyctiphanes in form but not in colour, they could be separated by careful study.

The egg (oosphere as it is termed by Sars) agrees exactly with those described by him. This is, however, not exclusively characteristic of Meganyctiphanes, as eggs of Thysanoessa inermis obtained from the parent and described below may be exactly the same size, but it will be shown that the larvæ of Thysanœssa are quite different. The size of the egg of Meganyctiphanes is $0.67 \mathrm{~mm}$. to $0.75 \mathrm{~mm}$. across (Plate IV, Figs. 1-2). It is perfectly transparent, and usually contains a pinkish embryo. Most of these were developing into nauplii. In one case an egg was entangled in a piece of transparent substance looking very much like the egg-sac of Nyctiphanes. It is thus possible that Meganyctiphanes may carry her eggs for a short time, although she has never been observed to do so, and against it is the fact that Sars found it free in the one-celled stage.

The nauplius may be seen inside the egg, still of a pinkish hue, and not nearly filling the whole of the capsule, which serves as a float. On emerging the first nauplius (Plate IV, Fig. 3) measures $0.48 \mathrm{~mm}$. in length, and has three pair of swimming limbs; the antennules uniramous with one long seta and the rudiments of a second, the antennæ and mandibles biramous, the antennæ with three and four setæ respectively to the rami, the mandibles with three to each ramus. The body is oval and perfectly simple with no hair-like processes behind, and is of a very pale pinkish hue. Muscles and yolk are seen inside the body, but no sign of alimentary canal. This is a perfectly typical euphausiid nauplius, and differs distinctly from the nauplius of Nyctiphanes found inside the egg-sac in that it has a biramous mandible. Almost immediately the first nauplius casts a very thin skin and becomes the second nauplius (Plate IV, Fig. 4), the same length as the first, but differing from it in having two processes at the hind end of the body, a median eye showing through the skin, the antennules with two long setæ and a rudimentary one, and the other two limbs being more fully developed: This nauplius still has a pale pinkish colour. Very soon the metanaupliar carapace and appendages can be seen under the skin of the older nauplius, and it changes by casting a very thin skin into the metanauplius. The metanauplius (Plate IV, 
Figs. $5,6,7)$ is $\theta .50$ to $0.52 \mathrm{~mm}$. long, having the carapace toothed all round, folded over the body ventrally and measuring ca $0 \cdot 42 \mathrm{~mm}$. long. A large flap, the upper lip, hangs over the mouth; the antennules bear three terminal setæ and a small lateral one, the antennæ have five and six setæ to the rami respectively, and the mandibles are reduced to a stump, which only shows traces of bifurcation. Behind the mandibles are the rudiments of the under lip and three pair of limbs show as simple knobs. The abdomen is nearly square, and bears eight to ten terminal setæ and three lateral setæ each side. When alive the two longest tail setæ and the two longest setæ on the front of the carapace stick up outside the plane of the others. The ocular plates and the rudiments of the luminous organs show faintly and certain internal organs are present, but the metanauplius does not appear to feed. The body has still a pinkish shade and differs besides this from the metanauplius of Nyctiphanes in having spines round the carapace, so that it can at once be distinguished from it. These stages from egg to metanauplius agree very well with those described by Sars (1898), as do also the Calyptopis stages. The eggs and nauplii described by Metschnikoff (1871) also bear a close resemblance. The nauplii from the eggs obtained from tow-nets in February were kept alive and turned into second nauplii and these into metanauplii, from which came the first Calyptopis, but rearing after this was unsuccessful. It was, however, possible to obtain the first Calyptopis from the tow-nets, and from it the second was secured, and the third from the second. Later stages were obtained from the plankton, and were very plentiful in spring and early summer up to late post-larval stages.

The Calyptopis stages are exceedingly like those of Nyctiphanes, differing, however, in colour and in being rather more heavily built. Later on they are much larger in the same stage of development, so that Nyctiphanes is in a post-larval stage when Meganyctiphanes of the same size is only a Furcilia.

The first Calyptopis of Meganyctiphanes is pinkish in colour with bright orange-red pigment diffusing outwards from two chromatophores in the thoracic region. Sometimes there are two pairs. Pigment is also present in the mouth region, and dorsally all along the body there is a diffuse pink shade. There are, however, no chromatophores on the telson as there are in Nyctiphanes, and by their pigmentation the species can be at once distinguished. In other respects the larvæ differ hardly at all (Plate II, Figs. 1 and 5). In the second Calyptopis the same colouring prevails, but Meganyctiphanes is slightly stouter in build, and at each successive stage the difference is more pronounced. There appears to be no important differences in the limbs of these stages in the two species. 
It is hoped to work out the later stages at a future time. It is sufficient for our present purpose to note that the later Furcilia and Cyrtopia stages were present in very large quantities in certain localities, and the postlarval stages of these showing specific characters were easily recognised, so that there seems to be no doubt about the identification.

\section{Thysanoessa neglecta (Kroyer) and Thysanoessa inermis (Kroyer).}

These two species are regarded as synonymous by Hansen (1911). In April, 1924, two specimens of $T$. inermis and one of $T$. neglecta were obtained from the Young Fish Trawl, and on a night trip in the same month a large number of both species were obtained together. Several of these were isolated in glass jars in order to obtain eggs from them, and eggs were shed by both species. Unfortunately it was not possible to rear these, those of $T$. neglecta not going beyond a four-celled stage, and that irregular and probably abnormal, those of $T$. inermis only reaching a spherical many-celled stage, and also usually developing irregularly. It is, however, the size of these eggs which is quite different in the two forms that primarily warrants one regarding them as distinct species. As Hansen justly remarks there is hardly any difference in the adults except for the long thoracic limbs in $T$. neglecta; but on close examination of the Plymouth specimens a distinct difference was found in the male modified first abdominal appendages, and there are apparently other slight differences which seem to be constant. A description of the adults and late larval stages is left for a future paper, but one seems to be justified in regarding these two as distinct species.

The eggs obtained from both speeies were shed freely into the water in the one-celled stage. Almost all the females had spermatophores attached ventrally, and these with the whole skin were cast just before the dropping of the eggs. The egg capsule of Thysanoessa neglecta (Plate V, Figs. 1-2) measured $0.41 \mathrm{~mm}$. to $0.54 \mathrm{~mm}$. across, the egg itself in the one-celled stage measuring $0.32 \mathrm{~mm}$. across, clear and transparent. The egg divided irregularly and probably abnormally into two and four cells and then died. Thysanoessa inermis shed its eggs in the same way, the egg capsule measuring $0.73 \mathrm{~mm}$. to $0.76 \mathrm{~mm}$. across (Plate V, Figs. 3, 4 and 5), the egg itself measuring $0.32 \mathrm{~mm}$. across, or rather more when developing irregularly, in which case no egg membrane could be seen. There is thus a very large space between egg and capsule, and the egg is very much like that of Meganyctiphanes. So far as was seen, however, it was perfectly colourless. These eggs all died after a few hours, and no more could be obtained.

There is thus shown to be a distinct difference between the eggs of Thysanoessa neglecta and $T$. inermis, although they are both shed freely 
into the water at the earliest stage and are of the same type. This is apparently the first time that the eggs of these euphausiids have been described, although Brook and Hoyle (1888) describe a small egg from the Clyde which probably belongs to Thysanoessa Raschii (Boreophausia). Sars (1898) states that he has "studied all phases of the larval development of a third form, probably Thysanoessa neglecta, the larvæ of which, especially in the more advanced stages, are easily distinguished from those of Nyctiphanes ... by their much more slender form." Apparently, however, these descriptions were not published, as I have not been able to find them. My own observations on the larvæ show that they are, as Sars states, of a much more slender form than Nyctiphanes and Meganyctiphanes.

There is a gap in the life-history of our two species of Thysanoessa, and the nauplii and metanauplii have not been described, nor, as far as I am aware, have they been seen. The next larval stage seen at Plymouth belongs to either Thysanoessa neglecta or $T$. inermis, but it is impossible at present to tell which. This, the first Calyptopis (Plate VI, Fig. 9), is much more slender than either Meganyctiphanes or Nyctiphanes, the abdomen being much longer in proportion to the carapace and on the telson is a pair of crimson-red chromatophores often merging into one mass. This larva, measuring $1.3 \mathrm{~mm}$. in length, is easily distinguishable from the same stage of Meganyctiphanes and Nyctiphanes, and is fairly common with them in the spring. The second Calyptopis (Plate VI, Fig. 10) measuring $2 \mathrm{~mm}$ in length, and the third (Plate VI, Fig. 11) measuring $2.56 \mathrm{~mm}$. in length, are also easily recognisable, the crimson chromatophores now being double, one pair above and one pair below the lateral spines of the telson. The elongated form is characteristic and also the elongated narrow carapace. The first Furcilia of this form (Plate VI, Fig. 12) has no abdominal appendages., This measures $3.04 \mathrm{~mm}$. in length. Several succeeding Furcilia stages were found, but it is in the Cyrtopia stage that two forms can be recognised, one with long second thoracic limbs, the other with them short, thus corresponding with Thysanoessa neglecta and $T$. inermis respectively. Either of these forms agrees well with the slender larvæ from which a series can be formed, and it is highly probable that both $T$. neglecta and $T$. inermis have very similar early larval stages. Their elucidation remains for future investigation. Enough has been shown, however, to prove that the slender larvæ belong to Thysanoessa, therefore as we know that a thick-set first Calyptopis closely resembling Nyctiphanes comes eventually from the egg which we have assumed to belong to Meganyctiphanes, and which is of the same size and form as the egg shed by Thysanoessa inermis, it seems safe to infer that we are truly dealing with the egg of Meganyctiphanes as described above, and that eventually we shall find coming 
from the eggs of Thysanoessa larvæ corresponding with these slender forms which can be followed up into later larval stages and shown to belong to this genus.

We are now in a position to compare the Calyptopis stages of Meganyctiphanes norvegica, Nyctiphanes Couchii and Thysanoessa sp. (either $T$. neglecta or $T$. inermis), and to distinguish them one from the other (Plate VI).

First CALyptopis, Meganyctiphanes norvegica, colour pinkish dorsally, bright orange-red in thoracic region, spreading out from two large chromatophores; pigment round mouth (length ca $1 \mathrm{~mm}$.). No pigment on telson. Nyctiphanes Couchii, orange-red chromatophores on telson only (length, ca $1 \mathrm{~mm}$.). Thysanoessa sp., much more slender than the other two in both carapace and abdomen. Crimson-red chromatophores in one patch on telson (length, $1.3 \mathrm{~mm}$.).

Second Calyptopis, Meganyctiphanes norvegica, same colour as before Rather stout build (length, $1.6 \mathrm{~mm}$.). Nyctiphanes Couchii, same pigment on telson, a little pigment near mouth. Less robust than Meganyctiphanes (length, 1.52 mm.). Thysanoessa sp. Two crimson-red patches on telson. Very much elongated (length, $2 \mathrm{~mm}$.).

ThIRD AND LAST CALYPTOPIS, Meganyctiphanes norvegica, same colour as before. Very robust (length, $2 \cdot 4 \mathrm{~mm}$.). Nyctiphanes Couchii, same colour as before. Much less robust than Meganyctiphanes (length, 2.08 mm.). Thysanoessa sp., same colour as before. Very slender (length, $2.56 \mathrm{~mm}$.).

The first Furcilia stages have the same characteristic pigmentation, and as they grow the stages are more and more easily recognised. Detailed descriptions of these later stages are reserved for a future paper.

\section{SUMMARY.}

It is shown in these notes that Nyctiphanes Couchii is an important food for Herring in the neighbourhood of Plymouth, and that this euphausiid and three others are common at times, either as larvæ or adult. It has been possible to procure the eggs of all these species and to rear those of Nyctiphanes through five larval stages direct from the parent, other stages being identified from the plankton. The young of Meganyctiphanes norvegica have been identified from eggs to late larvæ. The eggs of both Thysanoessa neglecta and $T$. inermis have been obtained from the parent, and, although these could not be reared, larvæ of Thysanoessa were recognised in the plankton. The importance of these observations lies chiefly 
in the fact that nearly all was done from living material, whereas in most of the researches on the subject the specimens have been preserved. The advantage of the living material is obvious, both for rearing purposes and for identification by pigment.

Much yet remains to be done, and it is reserved for the future to investigate further into the food of the Herring directly it arrives in the Plymouth waters, to deal with the detailed distribution of all species of euphausiids, both larvæ and adult, and to finish the detailed investigation of their larval stages.

\section{LITERATURE.}

1853. BeLL, T. British Stalk-eyed Crustacea. London.

1888. Brook, G., and Hoyle, W. E. The Metamorphosis of British Euphausiidæ. Proc. Roy. Soc., Edinburgh, July 2, 1888.

1924. Elmhirst, R. Annual Report, Scottish Marine Biological Association for 1922 .

1911. Hansen, H. J. The Genera and Species of the Order Euphausiacea, with Account of Remarkable Variation. Bull. de l'Inst. Océanographique, No. 210, May, 1911.

1905. Holt, E. W. L., ANd Tattersall, W. M. Schizopodous Crustacea from the North-East Atlantic Slope. Ann. Rep. Fish., Ireland, 1902-3, Pt. II, App. IV (1905).

1871 Metschnikoff, E. Ueber den Naupliuszustand von Euphausia. Zeit. f. Wiss. Zool., XXI, 4.

1906. Norman, A. M., and Scott, T. The Crustacea of Devon and Cornwall. London.

1885. SARS, G. O. Report on the Schizopoda collected by H.M.S. Challenger during the years $1873-6$.

1898. SARS, G. O. On the Propagation and Early Development of Euphausiidæ. Archiv. Math. Naturvid., 20.

1909. Zrmmer, C. Die Nordischen Schizopodon Nordisches Plankton, Vol. XII. 


\section{EXPLANATION OF PLATES.}

\section{PLATE I.}

FIG.

Nyctiphanes Couchii (all drawn to same scale).

1. Egg from pouch of,$+ 0 \cdot 36 \mathrm{~mm}$. across. Station El, surface, 9.4.24.

2. Nauplius from pouch of $ᄋ, 0.40 \mathrm{~mm}$. long. Same locality and date; dorsal view.

3. Nauplius from pouch of $9,0.44 \mathrm{~mm}$. long. Same locality and date; side view.

4. Nauplius, later stage, with metanaupliar limbs showing through skin, 0.54 mm. long; side view. From pouch of ㅇ․ Same locality and date.

5. Pseudo-metanauplius just emerged from pouch of $q, 0.56 \mathrm{~mm}$. long. Station L4, 30.4.24; side view.

6. The same; ventral view.

7. Metanauplius, from pseudo-metanauplius, reared in finger-bowl from ㅇ․ L4, 24.4.24. Changed its skin 2.5.24. $0.57 \mathrm{~mm}$. long; side view.

8. Metanauplius from same brood; dorsal view.

9. Metanauplius from same brood; ventro-lateral view.

\section{PLATE II.}

Nyctiphanes Couchii (all drawn to same scale).

1. lst Calyptopsis, T.N., L4, surface, 6.3.24. 0.99 mm. long ; dorsal view.

2. Mandibles of same.

3. 1st maxilla of same.

4. 2nd maxilla of same.

5. lst thoracic limb of same.

6. 2nd Calyptopis, T.N., L4, surface, 6.3.24. $1.44 \mathrm{~mm}$. long; ventral view.

7. Mandibles of same.

8. Ist maxilla of same.

9. 2nd maxilla of same.

10. 1st thoracic limb of same.

PLATE III.

Nyctiphanes Couchii (all drawn to same scale).

1. 3rd Calyptopis, T.N., L4, surface, 6.3.24. $1.92 \mathrm{~mm}$. long; dorsal view.

2. Under lip of same.

3. Mandible of same.

4. lst maxilla of same.

5. 2nd maxilla of same.

6. lst thoracic limb of same. 
PLATE IV.

Fig.

Meganyctiphanes norvegica (all drawn to same scale).

1. Egg with developing nauplius, T.N., L4, surface, 20.2.24. $0 \cdot 70 \mathrm{~mm}$. across.

2. Egg with later nauplius. Same locality and date.

3. Ist nauplius, from egg. Same locality and date. $0.48 \mathrm{~mm}$. long; dorsal view.

4. 2nd nauplius, from lst nauplius. Same locality and date. $0.48 \mathrm{~mm}$. long; dorsal view.

5. Metanauplius, from 2nd nauplius. Off Knap Buoy, 22.2.24. 0.51 mm. long ; dorsal view.

6. Metanauplius; ventral view.

7. Metanauplius; side view.

\section{PLATE V.}

Eggs of Thysanoessa (all drawn to same scale).

1. Egg of Thysanoessa neglecta, shed by ㅇ in glass jar. From 3 miles S.W. of Eddystone, 12.4.24, Y.F.T. $0.41 \mathrm{~mm}$. across.

2. Egg of Thysanoessa neglecta. Same locality and date, shed by 0 in glass jar. $0.52 \mathrm{~mm}$. across.

3-6. Eggs of Thysanoessa inermis, shed by $ᄋ$ in glass jar. From 3 miles S.W. of Eddystone, 12.4.24, Y.F.T. $0 \cdot 76 \mathrm{~mm}$. across. In various stages of segmentation $(3,5$ and 6 probably abnormal).

\section{PLATE VI.}

Meganyctiphanes, Nyctiphanes and Thysanoessa (all drawh to same scale).

1-4. Meganyctiphanes norvegica (all drawn to same scale).

1. 1st Calyptopis, from tow-nets. L4, 25.3.24. $1.02 \mathrm{~mm}$. long.

2. 2nd Calyptopis. Same locality and date. $1.6 \mathrm{~mm}$. long.

3. 3rd Calyptopis. Same locality and date. $2 \cdot 4 \mathrm{~mm}$. long.

4. 1st Furcilia. Station El, 9.4.24 (night). $2 \cdot 8 \mathrm{~mm}$. long.

\section{5-8. Nyctiphanes Couchii.}

5. lst Calyptopis, from tow-nets. L4, 9.3.24. $1 \mathrm{~mm}$. long.

6. 2nd Calyptopis. L4, 6.3.24 (night). $1.52 \mathrm{~mm}$. long.

7. 3rd Calyptopis. Same locality and date. $2.08 \mathrm{~mm}$. long.

8. Ist Furcilia, from last Calyptopis from 2nd from 1st Calyptopis (1st from T.N. L4, 17.3.24). $2 \cdot 56 \mathrm{~mm}$. long.

\section{9-12. Thysanoessa sp,}

9. Ist Calyptopis. T.N., E1 (night), 9.4.24. $1 \cdot 3 \mathrm{~mm}$. long.

10. 2nd Calyptopis. Y.F.T., Mewstone N.E. 4 miles, 26.3.24. $2 \mathrm{~mm}$. long.

11. 3rd Calyptopis. T.N., El (night), 9.4.24. 2.56 mm. long.

12. lst Furcilia. T.N., El (night), 9.4.24. 3.04 mm. long. 

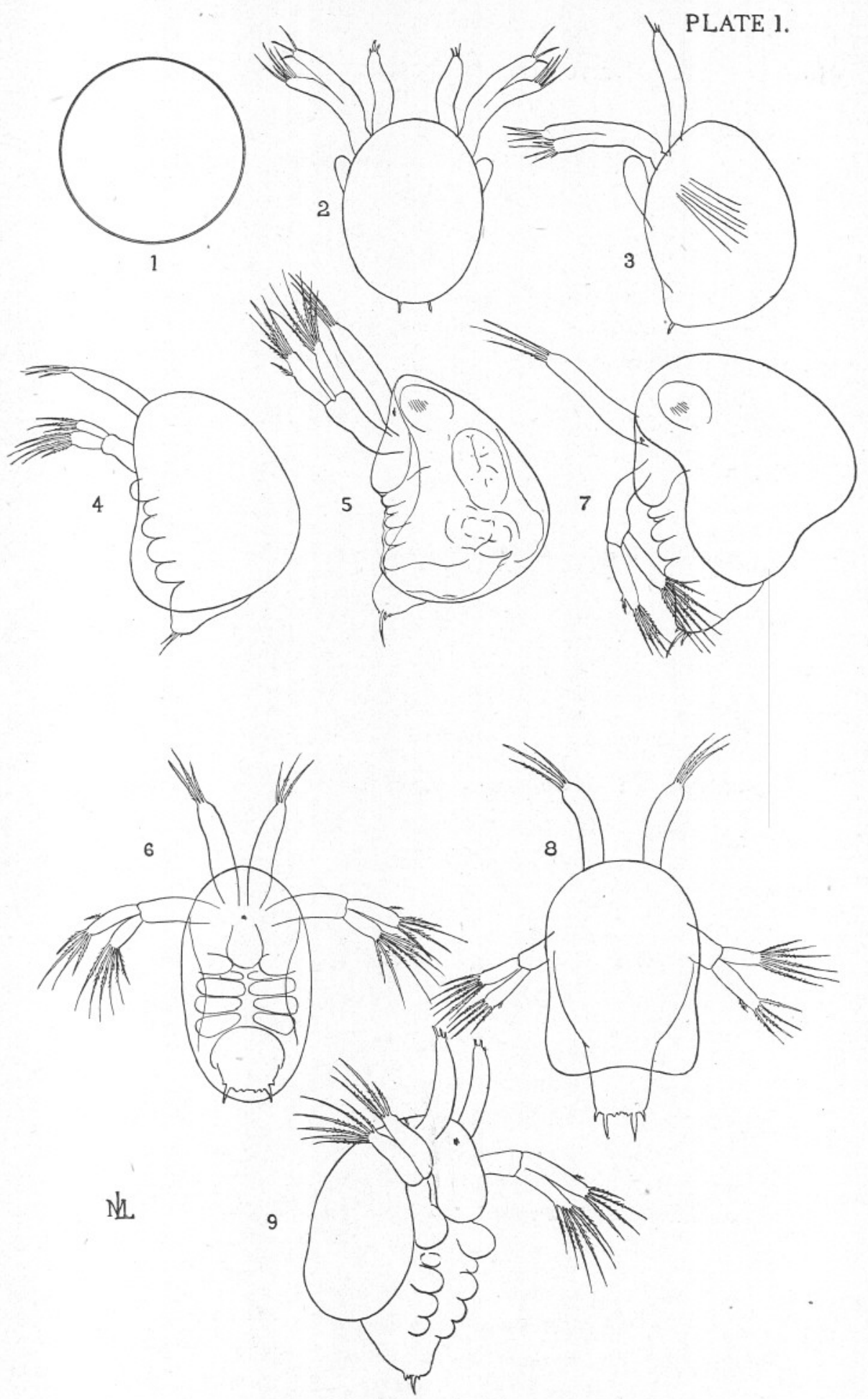

Nyctiphanes Couchii.

[421] 


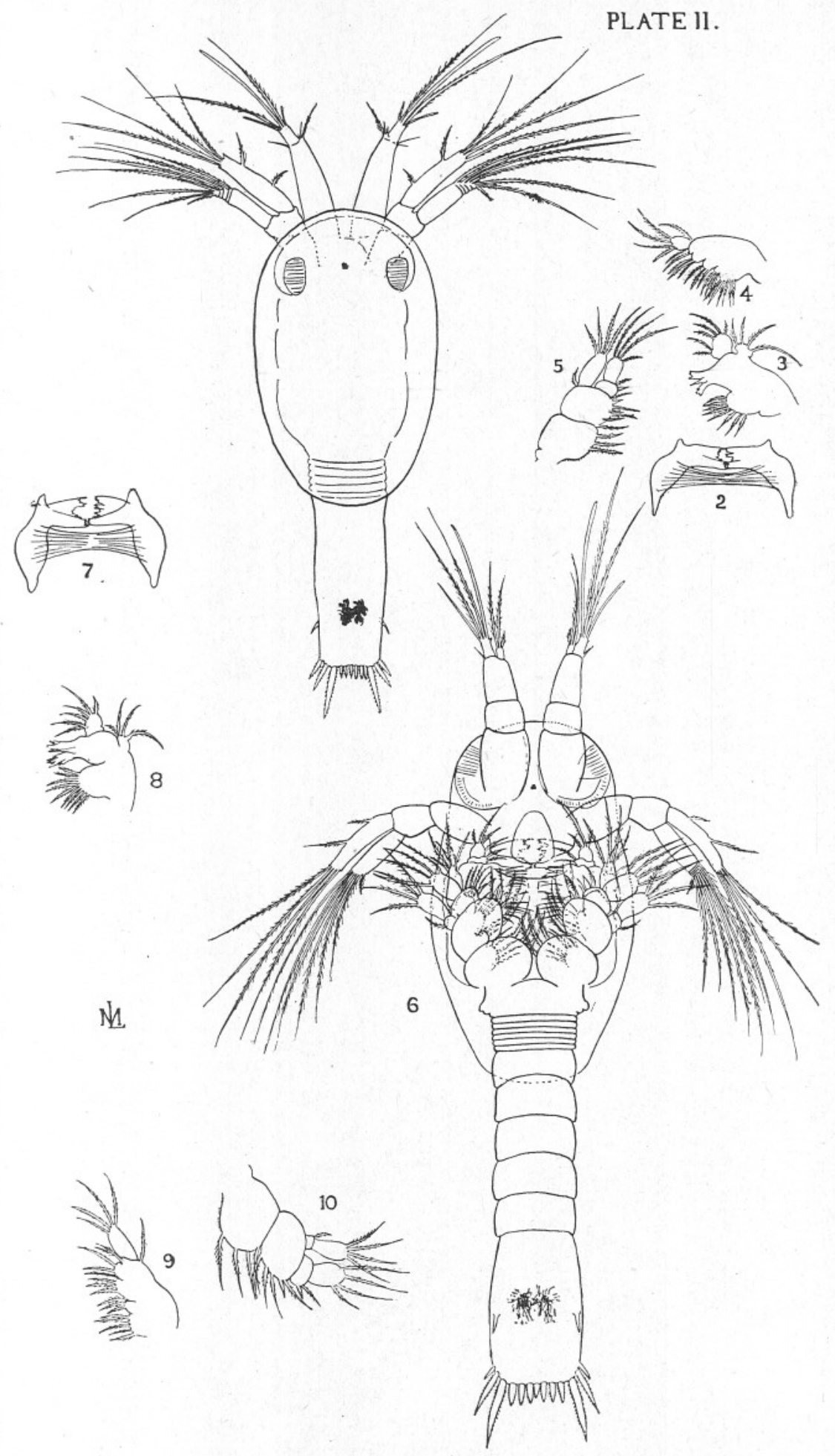

Nyctiphanes Couchii. 


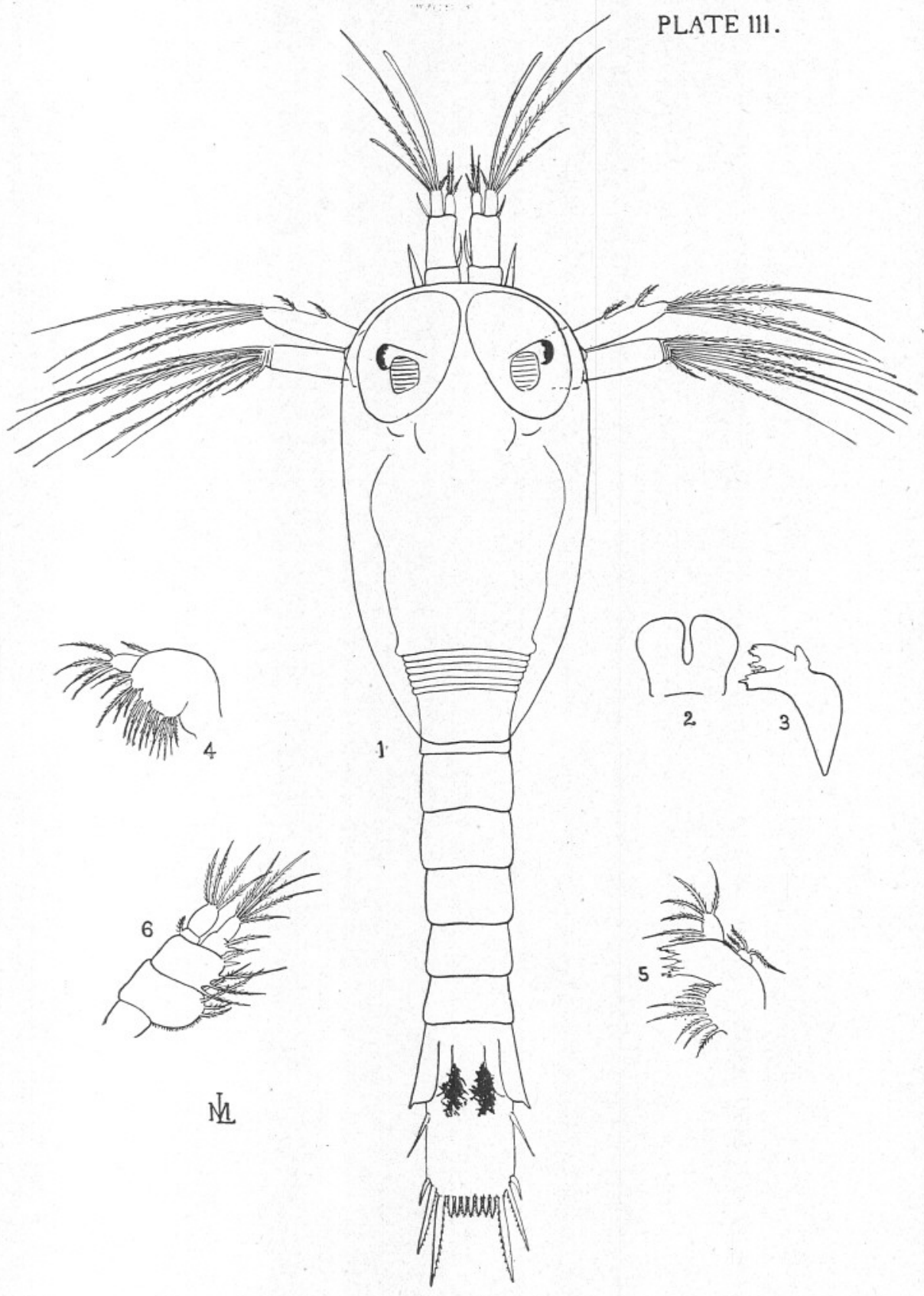

Nyctiphanes Couchii.

[ 425 ] 

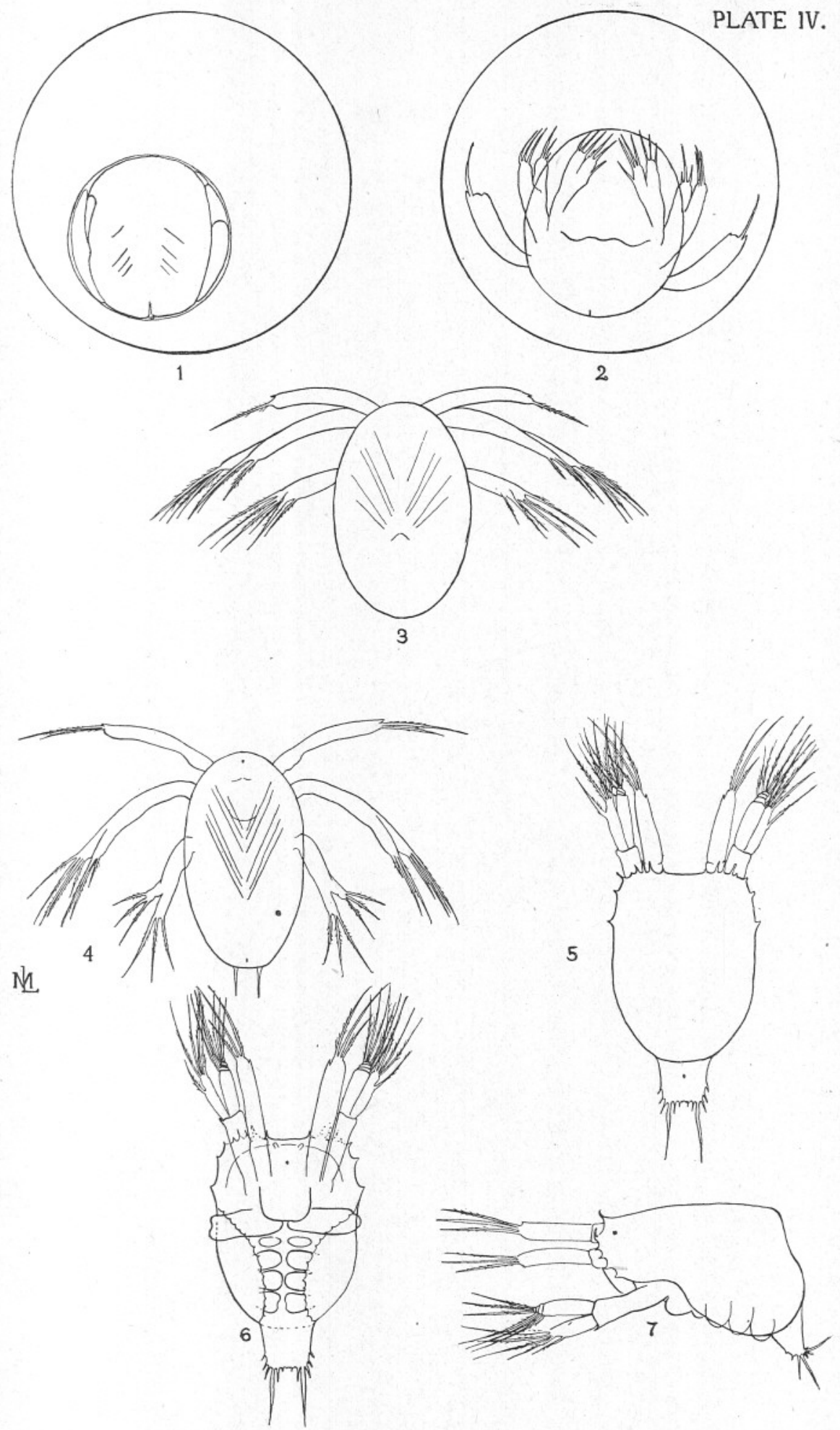

Meganyctiphanes norvegica.

[ 427 ] 

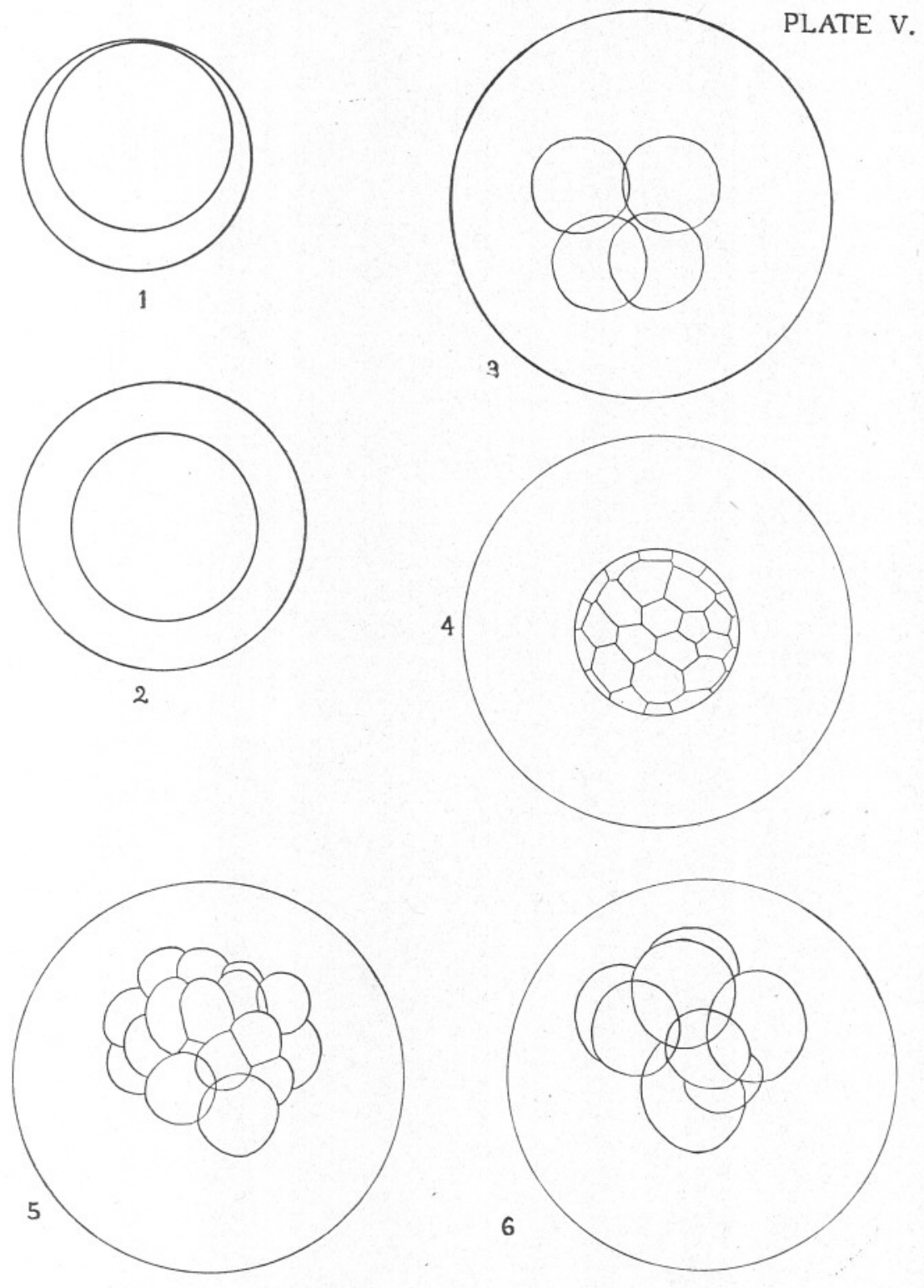

Figs. 1-2.-Thysanoessa neglecta.

, 3-6 , 6 inermis. 

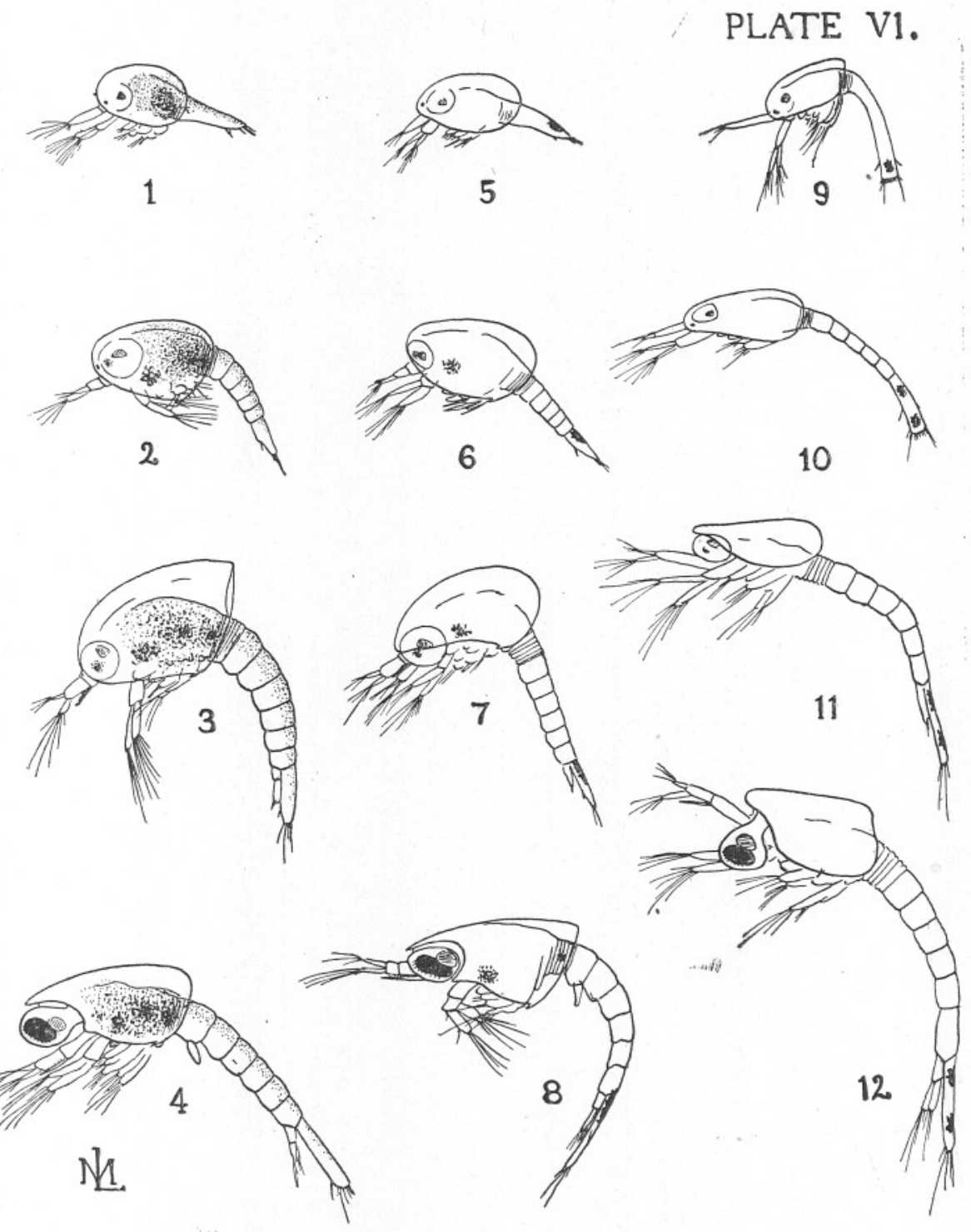

Figs. 1-4.-Meganyctiphanes norvegica.

,, 5-8.-Nyctiphanes Couchii.

", 9-12.-Thysanoessa sp.

\section{[ 431 ]}

NEW SERIES,-vol. XIII, No. 2. NOvember, 1924 . 